\title{
The Effect of Servant Leadership on Psychological Empowerment and Organizational Identification
}

\author{
Özcan ZORLU iDa Ali AVAN iDb Ahmet BAYTOK \\ aAfyon Kocatepe University, Department of Tourism Guidance, Afyonkarahisar, Turkey. ozcanzorlu@aku.edu.tr \\ bAfyon Kocatepe University, Tourism Management Department, Afyonkarahisar, Turkey. aliavan@aku.edu.tr \\ cAfyon Kocatepe University, Tourism Management Department, Afyonkarahisar, Turkey. ahmetbaytok@aku.edu.tr
}

\begin{tabular}{|c|c|}
\hline ARTICLE INFO & ABSTRACT \\
\hline $\begin{array}{l}\text { Keywords: } \\
\text { Servant Leadership }\end{array}$ & $\begin{array}{l}\text { Purpose - The aim of this study is to determine the effects of servant leadership on } \\
\text { psychological empowerment and organizational identification. }\end{array}$ \\
\hline $\begin{array}{l}\text { Empowerment } \\
\text { Psychological Empowerment } \\
\text { Organizational Identification }\end{array}$ & $\begin{array}{l}\text { Design/methodology/approach - Within the context of quantitative research approach, data } \\
\text { collected from } 309 \text { hotel employees by questionnaire. Reliability of data measured with } \\
\text { Cronbach's Alpha coefficient where the Factor analysis were performed to check validity. } \\
\text { Validity analysis has followed by Correlation and Regression analyses in which research } \\
\text { hypothesis were tested. }\end{array}$ \\
\hline $\begin{array}{l}\text { Received } 30 \text { November } 2018 \\
\text { Revised } 10 \text { February } 2019 \\
\text { Accepted } 18 \text { February } 2019\end{array}$ & $\begin{array}{l}\text { Findings - Results of the study assign that there is a significant relationship among servant } \\
\text { leadership, psychological empowerment and organizational identification. Furthermore, results } \\
\text { also support pre-assumptions suggesting that servant leadership behaviours significantly affect } \\
\text { psychological empowerment of employees and their identification process with the } \\
\text { organization. Within this context, empowerment and vision sub-dimensions of servant } \\
\text { leadership contribute psychological empowerment of hotel employees. Additionally, visionary } \\
\text { and humility behaviours of servant leaders increase the organizational identification level of } \\
\text { them. }\end{array}$ \\
\hline & $\begin{array}{l}\text { Discussion - Entrepreneurs in hospitality industry those who want to deliver high quality } \\
\text { service should consider to employ servant leaders/executives in order to have more empowered } \\
\text { and identified employees. Also, contributions of servant leaders are an important field for the } \\
\text { academicians, since they can create a positive and creative service philosophy among staff and } \\
\text { can heighten service quality. }\end{array}$ \\
\hline
\end{tabular}

\section{Introduction}

Today's competitive and successful organizations continuously make crucial investments on labour force as well as their technological capacities. Investments on labour force basically intend to have qualified employees who are committed to organization and performing beyond their executives' expectations. In this sense, psychological empowerment of an employee and his/her identification with the organization become more important in terms of organization efficiency and functioning (van Knippenberg and van Schie, 2000: 138). However, to achieve this, companies need to employ more talented executives and efficient leaders.

Due to the distinctive features and intensive competition, hospitality industry demands both task and people-oriented leaders much more. Hence, different leadership styles can be observed in hotel enterprises which are the dominant part of hospitality industry. For example, hotel enterprises prefer transformational leaders to adopt environmental changes and to accelerate needed changes, while they prefer service leaders much more at heightening service delivery. Sometimes they need authentic or spiritual leaders to motivate employees, and sometimes knowledge leaders are needed to enhance service knowledge.

Based on expectations, common goals and cooperate vision various leadership styles can be preferred at hotel enterprises. However, servant leadership approach is more preferred due to its critical elements. A servant leader can motivate and improve employees by visionary behaviours, empowerment, trust, agapao love and humility. Additionally, his/her altruistic behaviours are essential for at the moment of service 
delivery process, and his/her service desire to others plays a vital role for unexpected problems or conflictions. Servant leaders also play a moderator role for developing some desired attitudes and behaviours among employees such as commitment, citizenship behaviour, embeddedness, job/work satisfaction. Concordantly, servant leaders' crucial roles could help establishing a qualified and desired human resource at hotel enterprises. Namely servant leaders can support targeted organizational structure and help to improve employee skills. Among its many contributions, servant leaders can also empower their employees and strengthen them to have an organizational identity. Yet, studies about servant leadership are still limited in terms of providing a holistic view and determining how these leaders distinguish and make a difference at hotel enterprises. In this sense, this study offers some major contributions to the literature. We extend both the servant leadership literature and related outcomes in working environment such as organizational identification and psychological empowerment with a field study. The convergence of these research areas provides an opportunity to researchers to explore the relationship between these associated variables. Second, we take over the effects of dimensions of servant leadership on psychological empowerment and organizational identification. Thus, we intended to determine which dimensions of servant leadership empower employees in terms of active participating to decision process and organizational identification.

\section{Conceptual Framework}

\subsection{Servant Leadership}

Servant leadership (SL) concept mainly stemming from the experiences of Robert K. Greenleaf in management (Spears, 2010: 26), teachings of Jesus (Sendjaya and Sarros, 2002: 58) and the composition of Herman Hesse named as "Journey to the East". SL, which goes beyond the controversy where the concepts of service and leadership come together, is accepted as an important leadership approach for learning organizations by Bernard M. Bass (2000) and become a phenomenon for academic studies. By adopting the social exchange theory proposed by Blau (1964), SL moves from the "wellbeing of followers" doctrine.

SL generally associated with the concepts such as morale, authenticity, servanthood and spirituality. SL focuses on increasing the followers' performance and continuously develop them. Contrary to authentic, ethic and transformational leadership, in servant leadership, less pride of leadership is observed (Walumba et al., 2010). Bass (2000: 21) argues that transformational leaders try to keep their interests and the interests of others on the same plane with the group, organization or community benefits. Contrary to this, servant leaders continually strive to meet their followers' needs and demands (Van Dierendonck et al., 2014). Rather than being engaged in mobilizing followers to "perform beyond expectations" (Bass, 1985), servant leaders care for followers' holistic needs, development, and autonomy (Graham, 1991). Commitment to this fundamental value increases the possibility of the followers to be healthier, smarter, free, more autonomous and more servants in SL relationships (Bass, 2000: 33).

There is a genuinely service for the sake of others in SL, where humility is essential. Thus, conviction of heart is unintentionally speechmaker (Sendjava and Pekerti, 2010). And, this is a freehearted concern for the wellbeing of others, instead of an emotional effort. In SL, the desire to serve for others spontaneously substitute for organizational goals (Stone et al., 2004: 355). Hence, fundamentals of SL is to attract the attention of followers (Vondey, 2010).Winston (2003) argue that serving to followers will result in being served by his/her followers. Since all followers voluntarily (without any external pressure) accept to serve the leader instead of being leaded, SL is an effective leadership approach (Stone et al., 2004: 356).

It is important for various reasons that servant leaders encourage their followers to highly moral reasoning. Most of all, objective implementation of universal principles balance the personal interests to others' one. This also helps to reveal emotional and psychical reserves of followers to serve common good. Another reason is that followers are encouraged to apply their own ideas in order not to accept moral principles in which embraced by unpowerful or unattractive authority figures. Hence, selfishness and fragility diminish when people have the power to participate in a high level of moral reasoning. While serving at best, servant leaders are not only encourage their followers to objective moral reasoning but also encourage them to follow leader with constructive participation to organizational governance (Graham, 1995: 51). 
It is only possible to distinguish SL from other leadership approaches by observing its distinctive features and specific behaviours (Russell and Stone, 2002: 145). However, in the literature, the properties of SL are classified in different ways in various studies. Farling, Stone and Winston (1999) categorize SL's properties as vision, influence, credibility, trust, and service, while Page and Wong (2000) use character-orientation, people-orientation, task-orientation and process orientation. Spears (2004) argues properties of SL as listening, empathy, healing, awareness, persuasion, conceptualization, stewardship, foresight, commitment to growth and building to community. Sendjaya et al. (2008) and, Sendjeva and Pekerti (2010) prefer voluntarily support, authentic personality, contextual relationship, ethical responsibility, spirituality and transformative impact. Van Dierendonck et al. (2014) also evaluate these properties as empowering and developing people, humility, authenticity, interpersonal acceptance, providing direction and stewardship.

Russell and Stone (2002: 147), in their theoretical study which they assimilate the servant leadership attributes into a rational model, reveal SL attributes into 9 functional as dependent and 11 accompanying as moderating variables. Differently, Patterson evaluate SL in (7) seven dimensions as agapao love, humility, altruism, vision, trust, empowerment, and service. By evaluating Patterson's work, Winston (2003: 6) expanded Patterson's seven dimensions as followers-oriented: love of the followers, commitment to the leader, self-sufficiency, intrinsic motivation, and altruism to the leader and his/her interests. Cerff and Winston (2006: 5) added hope, Waddell (2006: 7) added introversion to Patterson's seven SL dimensions. Eventually, it is clear that the most of SL classifications has developed by considering Patterson's (2003) study.

The aim of Patterson's (2003) SL model is to define and develop the elements that make up SL, and to present the SL theory as the logical extension of transformational leadership. Patterson stated that SL was explained by the fact that focusing on the organization rather than the follower in which the transformational leadership was insufficient. The researcher states that SL is especially directed by virtue. Virtue in SL shapes leaders' attitudes, character and behaviours. And, agapao love is a milestone for leadership and for the relation of leader-follower. This love care about and consider the needs, wants and desires of follower. Agapao love is also related with altruism/sacrifice. A servant leader earns followers' respect and motivates them by love, altruism, humility.

Another prominent study about servant leadership belongs to Dennis and Bocarnea (2005) aims to develop an instrument for leadership assessment. Although authors used Patterson's SL scale, 42 items of 71, which is proposed at Patterson's study, were found valid. Additionally, findings of the study indicated that altruism and service sub-dimensions did not discriminated as a separate factor. Thus, analyses yield five factor similarly to Patterson's scale and sub-dimensions of SL named as empowerment, trust, humility, agapao love and vision (Dennis and Bocernea, 2005: 606-611). Dennis and Bocarnea's SL scale is also used in this study due to its similarity to Patterson's scale and its preferability in previous studies.

\section{2. Psychological Empowerment}

Derived from power and control notions, PE is defined briefly as sharing power with the followers (Conger and Kanungo, 1988: 473) or an authority that towards an employee's decision making without any approvals. As a misunderstanding, PE is perceived by many organizations of today's business environment as delegation of responsibilities by executives (Conger and Kanungo, 1988; Conger, 1989; Quinn and Spreitzer, 1997). PE is consisted of intrinsic motives occurred in an individual by after effect of motivational process of an individual's experience of feeling enabled (Corsun and Enz, 1999: 205). In other words, PE is a process that includes strengthening and altering inner believes by perceiving personal competence (Conger, 1989: 18). Thomas and Velthouse (1990: 668) defined empowerment in terms of intrinsic motivation and state that intrinsic task motivation involves positively valued experiences that individuals derive directly from a task. Conger and Kanungo (1988: 474) defined empowerment as "a process of enhancing feelings of selfefficacy among organizational members through the identification of conditions that foster powerlessness and through their removal by both formal organizational practices and informal techniques of providing efficacy information".

Empowerment has two main approaches: structural, which is also called as relational and psychological (Chan, Taylor and Markham, 2008: 445; Gkorezis, Hatzithomas and Petridou, 2011). While structural approach center upon managerial action through power sharing or granting of power and decision making 
Ö. Zorlu - A. Avan - A. Baytok 11/1 (2019) 293-309

sword (Menon, 2001), psychological approach of empowerment emphasizes the employee motivation and focuses on subjective evaluations of employees about organizational environment (Kim et al., 2012: 11).

Spreitzer (1995) emphasized that PE is a motivational construct and has four cognitions: meaning, competence, self-determination and impact. Functioning as the 'engine' of the empowerment (Spreitzer, Kizilos and Nason, 1997), meaning refers the value of a given task goal judged in relation to an individual's own ideals or standards. In other words, meaning connotate the intrinsic caring about a given task (Thomas and Velthouse, 1990: 672). Competence sub-dimension of PE basically refers to the degree to which a person can perform task activities skilfully when he or she tries (Thomas and Velthouse, 1990: 672). Competence means that employees are confident about their ability to do their work well (Quinn and Spreitzer, 1997: 41). Self-determination reflects whether individuals see themselves as the origin of their actions (Spreitzer, Kizilos and Nason, 1997: 682). Self-determination is the degree of freedom of employees to choose how to do their work without any approvals (Quinn and Spreitzer, 1997: 41). Thomas and Velthouse (1990: 473) named self-determination as choice, which is rather than a philosophical term, and defined as causal responsibility for a person's actions. Impact refers to perception of employees about their ability to impact on organizational outcomes (Chan, Taylor and Markham, 2008: 445).

\section{3. Organization Identification}

Organizational identification (OI) has emerged from the concept of individual conviction and the concept of coalescence -performing more effort dedicated to organization- (cited in Ashforth et al., 2008: 326), and discussed by Patchen (1979) in organizational context. Patchen emphasize that identification is used for describing various interrelated phenomena. Hereunder, feelings of solidarity with the organization, perceiving the support of the organization, perception of shared characteristics with other organizational members are main dimensions of OI. Likewise, Cheney (1983) discussed the concept of OI in three dimensions as "a) feelings of attachment, belonging and pride in being an organizational member, b) loyalty to the organization and support of the organization's goals, c) perceived similarity between employees and organization in terms of shared values and goals. Mael and Ashforth (1992: 103) in their extensive study define OI as "perceived oneness with an organization and the experience of the organization's successes and failures as one's own". Thus, OI also explain how a member of an organization has linked his or her organizational membership to his or her self-concept, either cognitively, emotionally (pride in membership), or both (Riketta, 2005: 361).

Organizational identification notion is being conceptualized from Social identity theory, and selfcategorization theory is also related phenomena with identification (Ashforth et al., 2008: 327). According to social identity theory, individuals are more likely to be identified with a group with compatible characteristics. Social identity theory suggest that individuals have a holistic perception of being subject to different groups sharing a common identity (Ashforth and Mael, 1989; Tajfel and Turner, 1986). Social categorization theory likewise argue that individuals categorize themselves and others according to different social categories, that they are being a member to certain groups in terms of their qualities. According to the theory, those individuals are also positioned themselves in various social categories within the context of their self-concepts. Organizational identification is a specific form of social identification. Social identification is the perception of oneness with or belongingness to a group (Ashforth and Mael, 1989) and social categorization has a voice in identification process. Tajfel's social identity dimensions have some arguments supporting these theories. Tajfel's social identity dimensions are:

1. a cognitive component, which is the knowledge of being a member of a certain group;

2. an affective dimension, which is the emotional attachment to that group; and

3. an evaluative aspect, which describes the value connotation assigned to that group from outside.

With reference to assumptions about social identity Tajfel and Turner (1986) made some theoretical inferences; (i) individuals strive to develop positive social identity, (ii) positive social identity can largely be based on positive comparisons between the group and some related external groups, (iii) individuals will strive to leave their existing group or to be subject to a different group when their social identity is not satisfactory. 
In literature, OI sometimes confused with different concepts such as organizational commitment (OC), organizational citizenship behaviours (OCB) and person-organization fit. Asforth and Mael (1989: 23) state that identification is different from organizational commitment, but various studies in literature are not sufficient to differentiate these two concepts. Organizational commitment suppose that individuals and organization are different entities, and commitment stemming from social exchange. However OI expresses deeper and existential tie that requires perceived association with the organization. OI is the perception of oneness with or belongingness to a group, involving direct or vicarious experience of its successes and failures (Ashforth and Mael, 1989: 34). Commitment is a relatively stable and lasting attitude. In contrast, organizational identification is more flexible (Gautam et al., 2004). Commitment is a broader concept which includes positive assessment of organization, hardworking for organization, continuation to stay at the organization and identification as well (Riketta and Dick, 2005: 491). Another concept confusing with OI, OCB is a voluntary behaviour without any expectation of reward and directly or explicitly not recognized by the official award system while it encourages company's efficient system by expressing some qualifies such as self-sacrifice, conscience and courteousness (Organ, 1988: 4). OI is an approach that empower OCB (Zhao et al., 2014). In this sense, it can be assumed that OI expose an expectation related with self-concept and being subjected to a group, and OCB is a promotive behaviour that encourage group members to develop supportive behaviours for enacting the group.

OI, also defined as the cognitive link between the definitions of the organization and the self-concept, is an identification of individual's own characteristics and the organization's characteristics perceived by him/her. Members of an organization differ according to their identification levels with the company. When they are strongly identified with the company, the characteristics they use to identify the organization also define themselves (Dutton et al., 1994: 242). The groups composed of individuals who have the same level of organizational identification or who define themselves as members of the same social category are called psychological groups by the Turner (1984: 530). Individuals who are members of this psychological group do not have to interact with or love other members. Further, psychological group may occur in various forms at different units of an organization.

Identification tends to occur even if there is no strong leadership or member loyalty, interaction and harmony. Furthermore, the concept of identification defines the cognition of oneness instead of any behaviour and effects that can function as precursors or consequences of cognition. Identification encourages the individual to participate in activities that are appropriate for identity, to being satisfied from these activities, and conventionally to reinforce elements of group formation (Ashforth and Mael, 1989). Organizational identification in which occurs when employees' socio-emotional needs are satisfied is the inclusion of company's goals in the employee's social identity (Frenkel and Yu, 2011: 389). Individuals who are strongly identified with the organization are more likely to overcome tasks that benefit the whole organization rather than individual benefits (Farrell and Oczkowski, 2012: 367). A strong OI also result in some desirable outcomes such as $\mathrm{OCB}$ and intra-organizational cooperation. However, if the members perceive negative organization image some undesired outcomes such as depression, stress, conflict and less effort in achieving long-term goals can also be observed (Dutton et al., 1994: 240). Self-contents of strongly identified members are identified by company identity. Therefore, other members/individuals of the organization play an important role in terms of self-content of an employee (Qi and Ming-Xia, 2014: 234).

\subsection{Servant Leadership and Psychological Empowerment}

In SL approach, leader is motivated by desire to serve and empower his/her followers. And, the impact resulting from the service of the servant leader, constitutes the essence of SL (Brownell, 2010: 366). SL based on respect for others and humility. Servant leaders embrace their followers with agapao love, value them and hold organization members together through established mutual trust. Mutual trust atmosphere established by SL support and accelerate empowerment process. Distinctive values of SL not only affect their followers' characteristics but also affect characteristics of organization (Russell, 2001: 81).

Servant leaders integrate participative management, team building, total quality and service orientation ideals to their leadership philosophy (Dutta and Khatri, 2017: 68). SL present an efficient leadership approach built on ethics-moral values and empowerment (Boyum, 2006), and focuses on the importance of appreciation, valorisation and empowerment of people (2004: 354). Empowerment process aims to develop a 
pro-active and confident attitude among followers, and give them a personal sense of power (van Dierendonck, 2011: 1232). This sense of power practically transmit to follower by servant leaders. SL behaviors do not increase the personal competence and skill levels of the members as existentially, but instead reinforce their perceptions as a result of their subjective evaluations about the organizational environment. As mentioned above, PE is a process of strengthening and altering inner believes (Conger, 1989) and consisted of intrinsic motives occurred in an individual by after effect of motivational process of an individual's experience of feeling enabled (Corsun and Enz, 1999: 205). Thus, it can be state that servant leaders play an important role in improving individuals' and organization's quality of life.

In literature, there are some studies addressing that empowerment is one of the most important dimensions of SL (Greasley and Bocârnea 2014; Jaiswal and Dhar, 2017; Liden et al. 2008; Page and Wong, 2000; Patterson, 2003; Russell and Stone, 2002; van Dierendonck 2011; van Dierendonck and Nuijten 2011). Although, existence of various studies directly subject the effects of SL on PE or the relationship between them (Baykal et al., 2018; Çetinkaya and Yıldız, 2018; Sousa and van Dierendonck, 2017; van der Hoven, 2014; Van Winkle et al., 2014), it is also possible to find some studies assessing the mediating role of PE in terms of the effect of SL on organizational outcomes (Allen et al., 2018; Asag-Gau and van Dierendonck, 2011; Khajehpour et al., 2016a; Khajehpour et al., 2016b; Newman et al., 2017). Van der Hoven (2014) and Van Winkle et al. (2014) ascertained that followers' perception of being empowered is positively relationship with supervisors' servant leadership behaviours. Sousa and van Dierendonck (2017) found that underestimation is the most powerful determinant within the context of servant leaders' effect on PE. AsagGau and van Dierendonck (2011) also found that empowerment of SL creates additional differences on PE and it is the most important dimension in terms of OC. Ashgar and Naseer (2017) found that psychological empowerment has a mediating role between servant leadership and positive job behaviours.

SL behaviours likely more affect perception of hospitality industry workers, since employees directly interact with the customers at service encounter and instant control of this interaction is not possible. Due to the intangibility of service, customers are in search of tangible clues and this necessitates exhibiting extra role behaviors of the organization members and to eliminate the disruptions that the service production processes can produce. Hence, SL approach have direct effect on demonstrating relevant tangibles. But, there is not any study concerning the effects of HL on PE levels of employees within the context of hospitality and tourism. Based on previous explanations given above and the gap in literature, the following hypothesis is suggested;

\section{$H_{1}$ : Servant leadership behaviours significantly affect psychological empowerment of hotel employees.}

\subsection{Servant Leadership and Organizational Identification}

OI, which is described as the relationship between organizations' identity and self-concept, is the perception about the harmony among individuals' self-identity features and certain features expressing the organization (Dutton et al., 1994). Though, the effects of SL on this perception is not extensively discussed in the literature. Along with the existence of limited studies directly subject SL's effect on OI, there are few studies addressing mediating or moderating role of OI between the relationship with SL and some organizational behaviours such as $\mathrm{OCB}$, employee voice behaviour, work-to-family enrichment (e.g. Chughtai, 2016; Vondey, 2010; Zhang et al., 2012). In addition, the relationship of certain variables that is affected by SL (job commitment, extra role behaviour, OCB) with OI is also discussed in literature (Riketta and Dick, 2005; Farrell and Oczkowski, 2012; Qi and Ming-Xia, 2014).

Riketta and Dick (2005) state that OI have stronger relationship with job commitment and extra role behaviour than intention to leave work and absenteeism. Farrell and Oczkowski (2012) revealed that identification between employer and employee have positive effects on OCB and being customer-oriented. The authors also claim that employees who have more positive experiences with executives will have better identification level and will be much more customer oriented.

Zhang et al. (2012) concluded that SL has a positive relation with work-to-family enrichment and OI is a mediator in this relationship. Qi and Ming-Xia (2014) inferred that trust to organization have a moderating effect on OI and employee voice. Similarly, Chughtai (2016) state that OI plays a mediating role on the effects of SL on employees' negative feedback seeking behaviours. Thomas et al. (2017) ascertained that servant 
leadership is positively associated with procedural justice, organizational collectivism, and organizational identification in family firms.

Studies about measuring how SL behaviours affect OI level of organization members (e.g. Schuh et al., 2012; Chughtai, 2016) contain important findings suggesting that SL behaviours directly or indirectly affect organizational outcomes. Schuh et al. (2012) in their study, assert that customer oriented service behaviours are positively related with OI. Because of highly identified customer-contact employees are motivated to pursue shared goals, they are likely to have positively approach behaviors to the organization (Schuh et al., 2012). Zhang et al. (2012) emphasize that servant leaders instil and reinforce the importance of serving individuals with their behaviours. Accordingly, to serve others give important hints how it is a distinctive feature of organization. Moreover, it enables the organization to be seen as an organization that provides a nourishing environment for the growth and development of employees and shapes positive views on the organization image. Therefore, employees tend to feel strongly identified with the organization. Based on this perspective articulated by Zhang et al. and the propositions of literature, the following hypothesis is proposed to determine how SL will have an effect on the levels of OI of employees.

$\mathrm{H}_{2}$ : Servant leadership behaviours significantly affect organizational identification of hotel employees.

\section{Methodology}

In this study, it is aimed to reveal any potential effects of servant leadership (SE) on psychological empowerment (PE) and organizational identification (OI) within the context of hotel businesses. Data used in the study were collected by questionnaire technique from 338 hotel employees in November 2017 and April 2018. However, 29 questionnaires were excluded from analysis process due to the incorrect or incomplete filling. The questionnaire form basically consists of three sections beginning with some demographic questions to participants. 25 statements in the first section are aimed to determine servant leadership behaviours which is also used by Dennis and Bocarnea (2005). This section is followed by 12 statements related with psychological empowerment that adopted from Spreitzer (1995). The final section of the form consists 6 statements measuring organizational identification that adopted from Mael and Asforth's study conducted in 1992. All 43 statements in three sections organized to 5 point Likert scale ranging from "strongly disagree" to "strongly agree" and checked by four experts in terms of meaning and linguistic validity. For this purpose, all statements translated in Turkish by the authors mailed two experts to translate in English, meanwhile to other expert translate original statements to Turkish. Translation results were similar at the rate of \%92 to original statements and there were a major similarity (\%96) in the context of English to Turkish translation.

At the beginning of analysis process, validation (Factor analysis) and reliability (Cronbach's Alpha) tests were performed. Then, correlation analysis was carried out to determine any possible statistically meaningful relationship among dependent and independent variables of the study. And, bivariatemultivariate regression analyses were performed in order to calculate the potential effects and, also to test hypothesis of the study.

\subsection{Validation and Reliability}

This section mainly purpose to assign whether data of study is appropriate for the further analysis (correlation and regression analysis). Within this scope, validation of research scales was calculated with factor analysis, and reliability was calculated with Cronbach's Alpha coefficient. In table 1, results of the validation and reliability tests for servant leadership scale is given. From the Table 1, it is clear that 25 statements about servant leadership behaviours refer to \%64.929 variance of total with the 0.947 scale reliability. 
Ö. Zorlu - A. Avan - A. Baytok 11/1 (2019) 293-309

Table 1. Validation and Reliability for Servant Leadership Scale

\begin{tabular}{|c|c|c|c|c|c|c|c|}
\hline Sub-factors & Items & $\begin{array}{c}\text { Factor } \\
\text { loadings }\end{array}$ & $\begin{array}{l}\text { Eigen- } \\
\text { values }\end{array}$ & $\begin{array}{l}\text { Cumulative } \\
\% \text { variance }\end{array}$ & Factor Mean & Reliability & $\begin{array}{c}\text { Scale } \\
\text { reliability }\end{array}$ \\
\hline \multirow{5}{*}{ Empowerment } & SL8 & .774 & \multirow{5}{*}{11.199} & \multirow{5}{*}{44.797} & \multirow{5}{*}{3.889} & \multirow{5}{*}{.867} & \\
\hline & SL9 & .727 & & & & & \\
\hline & SL7 & .725 & & & & & \\
\hline & SL10 & .599 & & & & & \\
\hline & SL6 & .578 & & & & & \\
\hline \multirow{5}{*}{ Trust } & SL17 & .750 & \multirow{5}{*}{1.502} & \multirow{5}{*}{50.806} & \multirow{5}{*}{3.960} & \multirow{5}{*}{.860} & \\
\hline & SL18 & .680 & & & & & \\
\hline & SL20 & .607 & & & & & \\
\hline & SL19 & .565 & & & & & \\
\hline & SL16 & .543 & & & & & \\
\hline \multirow{5}{*}{ Humility } & SL22 & .730 & \multirow{5}{*}{1.284} & \multirow{5}{*}{55.943} & \multirow{5}{*}{3.596} & \multirow{5}{*}{.830} & \\
\hline & SL24 & .728 & & & & & \\
\hline & SL21 & .711 & & & & & .947 \\
\hline & SL25 & .666 & & & & & \\
\hline & SL23 & .455 & & & & & \\
\hline \multirow{5}{*}{ Agapao Love } & SL4 & .683 & \multirow{5}{*}{1.198} & \multirow{5}{*}{60.734} & \multirow{5}{*}{3.775} & \multirow{5}{*}{.822} & \\
\hline & SL3 & .683 & & & & & \\
\hline & SL1 & .619 & & & & & \\
\hline & SL2 & .606 & & & & & \\
\hline & SL5 & .600 & & & & & \\
\hline \multirow{5}{*}{ Vision } & $\begin{array}{l}\text { SL14 } \\
\end{array}$ & .778 & \multirow{5}{*}{1.049} & \multirow{5}{*}{64.929} & \multirow{5}{*}{3.372} & \multirow{5}{*}{.841} & \\
\hline & SL15 & .772 & & & & & \\
\hline & SL11 & .622 & & & & & \\
\hline & SL12 & .493 & & & & & \\
\hline & SL13 & .381 & & & & & \\
\hline
\end{tabular}

Kaiser-Meyer-Olkin Measure of Sampling Adequacy: 0.938

Bartlett's Test of Sphericity Approx. Chi-Square: 4483.967

Bartlett's Test of Sphericity Significance: 0.000

The fact remains that servant leadership behaviours have five (5) sub-factors which are also matching to Dennis and Bocarnea's (2005) research. Within this construct, empowerment behaviours are the most important sub-factor of SL with the 11.199 eigenvalues and \%44.797 variance. Trust sub-factor has \%6.009 variance while it is accounted as \%5.137 for humility. Agapao love and vision sub-factors are also an important part of SL by explaining \%4.791 and \%4.195 of variance in turn. Table 1 results also indicate that sub-factors of SL are reliable due to the significant coefficients which are all above 0.70 . Thus, it is concluded that SL scale and it's sub factors are valid and reliable for further analysis.

Validation and reliability analysis results were given in Table 2. As seen in the Table 2 psychological empowerment scale is valid for factor analysis (KMO: 0.866, Barttlett's test: 0.000) and measured with four (4) sub-factors (mean, impact, self-determination, competence) in this study. Further, the scale is reliable for detailed analysis with respect to its Cronbach's Alpha coefficient accounted for .892 .

According to the results of Table 2, mean sub-factor of PE scale is main determiner of PE applications due to the fact that it has 5.594 eigenvalue and \%46.614 variance explanation. While impact sub-factor constitutes another important structure for PE with is 2.339 eigenvalue and \%19.492 variance, self-determination and competence dimensions of PE relatively have lower eigenvalues and variance explanation ratios. But, all sub-factors of PE scale are reliable, since their reliability values are higher than .70. Thus, PE scale and its sub-factors are valid and reliable for further analysis. 
Ö. Zorlu - A. Avan - A. Baytok 11/1 (2019) 293-309

Table 2. Validation and Reliability for Psychological Empowerment Scale

\begin{tabular}{|c|c|c|c|c|c|c|c|}
\hline Sub-factors & Items & $\begin{array}{c}\text { Factor } \\
\text { loadings }\end{array}$ & $\begin{array}{l}\text { Eigen- } \\
\text { values }\end{array}$ & $\begin{array}{l}\text { Cumulative } \\
\% \text { variance }\end{array}$ & Factor Mean & Reliability & $\begin{array}{c}\text { Scale } \\
\text { reliability }\end{array}$ \\
\hline \multirow{3}{*}{ Mean } & PE1 & .908 & & & & & \multirow{12}{*}{.892} \\
\hline & PE3 & .878 & 5.594 & 46.614 & 4.526 & .914 & \\
\hline & PE2 & .866 & & & & & \\
\hline \multirow{3}{*}{ Impact } & PE11 & .884 & \multirow{3}{*}{2.339} & \multirow{3}{*}{66.106} & \multirow{3}{*}{3.498} & \multirow{3}{*}{.921} & \\
\hline & PE12 & .871 & & & & & \\
\hline & PE10 & .830 & & & & & \\
\hline \multirow{3}{*}{$\begin{array}{c}\text { Self } \\
\text { determination }\end{array}$} & PE8 & .834 & \multirow{3}{*}{.956} & \multirow{3}{*}{74.074} & \multirow{3}{*}{3.765} & \multirow{3}{*}{.838} & \\
\hline & PE7 & .788 & & & & & \\
\hline & PE9 & .785 & & & & & \\
\hline \multirow{3}{*}{ Competence } & PE5 & .792 & \multirow{3}{*}{.823} & \multirow{3}{*}{80.932} & \multirow{3}{*}{4.297} & \multirow{3}{*}{.779} & \\
\hline & PE4 & .784 & & & & & \\
\hline & PE6 & .638 & & & & & \\
\hline
\end{tabular}

Kaiser-Meyer-Olkin (KMO) Measure of Sampling Adequacy: 0.866

Bartlett's Test of Sphericity Approx. Chi-Square: 2503.274

Bartlett's Test of Sphericity Significance: 0.000

Scale validation and reliability tests end up with organizational identification scale. However, factor analysis for OI indicates that OI construct have no sub-factor and it is also valid for further analysis, since its KMO value is .845, Barttlett's test score is $576.324(\alpha: 0.000)$, Cronbach's Alpha coefficient ise .821 . Six items of OI explains \%53,501 and factor loadings of the items are all above .647. In sum, organizational identification level of participants has measured with single structured scale consisting of 6 items.

\subsection{Hypothesis Testing and Findings}

This part of the study mainly includes correlation and regression analysis, which are aimed to test research hypothesis. As mentioned before there are two hypotheses in the study, and servant leadership behaviours are considered as independent variables due to its estimated effects on PE and OI. On the other hand, existence and degree of servant leadership, psychological empowerment level, and organizational identification levels of employees are the preconditions for determining any significant effect among these variables. Thus, mean levels of three variables presented in table 3.

As seen in the Table, executives highly exhibit servant leadership behaviours ( $x: 3.718)$, while participants of the study are psychological empowered by various techniques $(\bar{x} 4.021)$, and their organizational identification level is relatively high $(\bar{x}$ : 4.013).

Results of the Table 3 are also confirming the existence of statistically significant relationships among independent and dependent variables. For instance, there are relatively strong correlation between SL and PE (r: .553). This correlation can also be counted for the relationship between SL and OI (r: .488). Additionally, the relationship between PE and OI (r: 525) is significant since the correlation coefficient higher than .50 . 
Ö. Zorlu - A. Avan - A. Baytok 11/1 (2019) 293-309

Table 3. Mean and Correlation coefficients

\begin{tabular}{|c|c|c|c|c|c|c|c|c|c|c|c|c|}
\hline & Mean & SLE & SLT & SLH & SLAL & SLV & $\begin{array}{l}\text { SL } \\
\text { total }\end{array}$ & PEM & PEI & PES & PEC & PE total \\
\hline SL empowerment (SLE) & 3.889 & 1 & & & & & & & & & & \\
\hline SL trust (SLT) & 3.960 & $.701^{* *}$ & 1 & & & & & & & & & \\
\hline SL humility (SLH) & 3.596 & $.563^{* *}$ & $.655^{* *}$ & 1 & & & & & & & & \\
\hline SL agapoe love (SLAL) & 3.775 & $.623^{* *}$ & $.666^{* *}$ & $.591^{* *}$ & 1 & & & & & & & \\
\hline SL vision (SLV) & 3.372 & $.692^{* *}$ & $.681^{* *}$ & $.612^{* *}$ & $.662^{* *}$ & 1 & & & & & & \\
\hline SL (total) & 3.718 & $.845^{* *}$ & $.872^{* *}$ & $.813^{* *}$ & $.835^{* *}$ & $.866^{* * 4}$ & 1 & & & & & \\
\hline PE mean (PEM) & 4.526 & $.382^{* *}$ & $.440^{* *}$ & $.302^{* *}$ & $.448^{* *}$ & $.297^{* *}$ & $.439^{* * 4}$ & 1 & & & & \\
\hline PE impact (PEI) & 3.498 & $.383^{* *}$ & $.345^{* *}$ & $.336^{* *}$ & $.346^{* *}$ & $.492^{2 *}$ & $.452^{2 *}$ & $283^{* *}$ & 1 & & & \\
\hline PE self-determination (PES) & 3.765 & $387^{* *}$ & $.360^{* *}$ & $339^{* *}$ & $.328^{* *}$ & $.456^{* *}$ & $.443^{3 * 4}$ & $.276^{* *}$ & $.628^{* *}$ & 1 & & \\
\hline PE competence (PEC) & 4.297 & $347^{* *}$ & $.324^{* *}$ & $.302^{* *}$ & $289^{* *}$ & $.288^{* *}$ & $.366^{* *}$ & $.569^{* * *}$ & $.462^{* *}$ & $.495^{* *}$ & 1 & \\
\hline PE (total) & 4.021 & $.485^{* *}$ & $.467^{* *}$ & $.417^{* *}$ & $.449^{* *}$ & $.520^{* *}$ & $.553^{3 *}$ & $.609^{* *}$ & $.839^{* *}$ & $.825^{* *}$ & $.768^{* *}$ & 1 \\
\hline OI (total) & 4.013 & $351^{* *}$ & $.402^{* *}$ & $.451^{* *}$ & $.412^{* *}$ & $.442^{2 *}$ & $.488^{* *}$ & $.466^{* *}$ & $390^{* *}$ & $385^{* *}$ & $.418^{* *}$ & $525^{* *}$ \\
\hline
\end{tabular}

Based on the correlation analysis results, the next phase of the study consists regression analyses, which are aimed to test research hypothesis. Within this scope $\boldsymbol{H}_{1}$ hypothesis of the study is tested with bivariate regression analysis and the results shown in Table 4.

Table 4. The effect of servant leadership behaviours on psychological empowerment

\begin{tabular}{|c|c|c|c|c|c|c|}
\hline & \multirow{2}{*}{ Model } & \multicolumn{2}{|c|}{ Unstandardized Coefficients } & \multirow{2}{*}{$\begin{array}{c}\text { Standardized Coefficients } \\
\text { Beta }\end{array}$} & \multirow{2}{*}{$t$} & \multirow{2}{*}{ Sig. } \\
\hline & & B & Std. Error & & & \\
\hline \multirow{2}{*}{1} & (Constant) & 2,120 & , 166 & -- & 12,731 & 000 \\
\hline & $S L$ &, 511 & ,044 & ,553 & 11,642 &, $000^{*}$ \\
\hline
\end{tabular}

\begin{tabular}{llll}
\hline a. Dependent Variable: PE & Adjusted R2: 0.304 & F: 135.528 & $\alpha: 0.000$
\end{tabular}

According to the results in Table 4, the regression model is valid (F: 135.528, $\alpha: 0.000)$ and regression model is "PE=2.120 + $0.511 \times S L$ ". In detail, SL behaviours represent the \%30 of total variance of PE while each increment at SL behaviours of executives increase PE level of participants at the rate of \%51. Thus, SL behaviours are very important for enabling psychologically empowerment at hotel enterprises. Form this fact, we accepted the first hypothesis $\left(H_{1}\right)$ of the study, which claims "SL behaviours are significantly affect PE of hotel employees".

With acceptance of $H_{1}$ hypothesis, the necessity to answer another critical question arises: Which SL behaviours significantly affect PE of participants? To find an answer this question multivariate regression analysis was performed shown in Table 5 . The results of analysis basically underpin $\mathrm{H}_{1}$ hypothesis and indicate that regression model is significant (F: 27.900, $\alpha$ : 0.000).

Table 5. The effects of sub-behaviours of SL on psychological empowerment

\begin{tabular}{|c|c|c|c|c|c|c|}
\hline & \multirow{2}{*}{ Model } & \multicolumn{2}{|c|}{ Unstandardized Coefficients } & \multirow{2}{*}{$\begin{array}{c}\text { Standardized Coefficients } \\
\text { Beta }\end{array}$} & \multirow{2}{*}{$t$} & \multirow{2}{*}{ Sig. } \\
\hline & & B & Std. Error & & & \\
\hline \multirow{6}{*}{1} & (Constant) & 2,184 & ,174 & -- & 12,536 & ,000 \\
\hline & SL: empowerment & 127 & ,059 & 160 & 2,161 &, $032^{*}$ \\
\hline & SL: trust & ,064 & ,065 & ,078 & 988 & ,324 \\
\hline & SL: humility & ,049 & , 050 & ,065 & ,969 & ,333 \\
\hline & SL: agapoe love & 071 & 057 & 088 & 1,243 & 215 \\
\hline & SL: vision & 191 & ,056 & ,258 & 3,392 &, $001^{*}$ \\
\hline
\end{tabular}

a. Dependent Variable: PE

Adjusted R': 0.304

F: 27.900

$\alpha: 0.000$

In the context of research sample, servant leaders in hotel enterprises empower their subordinates psychologically by sharing/articulating a vision $(\beta: 0.191, \alpha: 0.001)$ and various applications that empower ( $\beta$ : $0.127, \alpha: 0.001)$ them. In other words, one increment in sharing/articulating vision behaviours contributes psychological empowerment at the rate of $\% 19$, and this contribution is $\% 12,7$ for empowerment efforts. 


$$
\text { Ö. Zorlu - A. Avan - A. Baytok 11/1 (2019) 293-309 }
$$

The effect of SL on PE is also measured with in depth regression analysis within the context of organizational identification sub-dimensions. According to the results, agapoe love of servant leader ( $\beta$ : $0.249, \alpha: 0.000)$ and trust to him/her $(\beta: 0.225, \alpha: 0.001)$ significantly affect mean sub-dimension of PE while visionary behaviours of servant leaders affect impact sub-dimension of PE at rate of \%53.1 ( $\alpha$ : 0.000). Visionary behaviours of servant leaders are also affect employees' PE in the context of self-determination ( $\beta$ : $0.362, \alpha: 0.000)$, and leaders' various behaviours towards empowerment affect employees' competence ( $\beta$ : $0.161, \alpha: 0.016)$ which is a sub-dimension of PE. In sum, visionary behaviours, empowerment efforts, agapoe love and trust are the main determinants of servant leaders for psychologically empower their subordinates with respect to sub-dimensions of PE.

Depending on the aim of research, the effect of SL on OI in the next stage of the analysis was measured with bivariate regression. Results presented in Table 6 demonstrate that SL behaviours of executives represent $\% 23$ of organizational identification's total variance. In this significant regression model (F: 95.755, $\alpha: 0.000$ ) the effect of SL on OI mathematically formulate as "OI=2.056 + 0.526 $x S L$ "

Table 6. The effect of servant leadership behaviours on organizational identification

\begin{tabular}{|c|c|c|c|c|c|c|}
\hline & \multirow{2}{*}{ Model } & \multicolumn{2}{|c|}{ Unstandardized Coefficients } & \multirow{2}{*}{$\begin{array}{c}\text { Standardized Coefficients } \\
\text { Beta }\end{array}$} & \multirow{2}{*}{$t$} & \multirow{2}{*}{ Sig. } \\
\hline & & B & Std. Error & & & \\
\hline \multirow{2}{*}{1} & (Constant) & 2,056 & ,204 & -- & 10,082 &, 000 \\
\hline & $S L$ &, 526 & ,054 & ,488 & 9,785 &, 000 \\
\hline
\end{tabular}

With parallel to results in Table 6, each increment at SL increase the identification level of employees at the rate of \%52.6. Therefore, second $\left(\boldsymbol{H}_{2}\right)$ hypothesis of the study referring "SL behaviours significantly affect OI" is accepted. However, which behaviours of SL have significant effect on OI is still need to be determine.

Table 7. The effects of sub-behaviours of SL on organizational identification

\begin{tabular}{|c|c|c|c|c|c|c|}
\hline & \multirow{2}{*}{ Model } & \multicolumn{2}{|c|}{ Unstandardized Coefficients } & \multirow{2}{*}{$\begin{array}{c}\text { Standardized Coefficients } \\
\text { Beta }\end{array}$} & \multirow{2}{*}{$t$} & \multirow{2}{*}{ Sig. } \\
\hline & & B & Std. Error & & & \\
\hline \multirow{6}{*}{1} & (Constant) & 2,163 & ,212 & & 10,204 & 000 \\
\hline & SL: empowerment &,- 037 & 072 &,- 040 &,- 511 & 609 \\
\hline & SL: trust & ,046 & 079 & ,048 &, 583 &, 560 \\
\hline & SL: humility & ,212 & ,061 & 241 & 3,448 &, $001^{*}$ \\
\hline & SL: agapoe love & 119 & ,070 & 127 & 1,716 & ,087 \\
\hline & SL: vision & ,177 &, 069 & 205 & 2,582 &, $010^{*}$ \\
\hline \multicolumn{2}{|c|}{ a. Dependent Variable: $\mathrm{C}$} & $\mathrm{OI}$ & ted $\mathbf{R}^{2}: 0.245$ & F: 20.939 & \multicolumn{2}{|c|}{$\alpha: 0.000$} \\
\hline
\end{tabular}

In Table 7, the results of multivariate regression analysis are given which is aimed to calculate the effects of SL sub-dimensions on OI. With respect to results, humility of executives $(\beta: 0.212, \alpha: 0.001)$ and their visionary behaviours $(\beta: 0.177, \alpha: 0.010)$ are the main influencers of SL on employee's organizational identification.

\section{Discussion and Conclusion}

The major contribution of this research is the assertion of the strong relationship among servant leadership, psychological empowerment and organizational identification. All of two hypotheses were supported, suggesting that SL has a significant effect on PE (H1) and OI (H2).

According to the results, empowerment behaviours are the most important sub-factor of SL. This finding supported the arguments that empowerment is one of the most important dimensions of SL (e.g. Greasley and Bocârnea 2014; Jaiswal and Dhar, 2017; Patterson, 2003; Russell and Stone, 2002). Results also support pre-assumptions suggesting that SL behaviours significantly affect PE of employees and their identification process with the organization. The perception of SL behaviours of supervisors is relatively high $(x \overline{:} 3.718)$, while subordinates are psychologically empowered by various techniques ( $\overline{\mathrm{x}}: 4.021)$, and their OI level is considerably high ( $\bar{x} \overline{:} 4.013)$. 


$$
\text { Ö. Zorlu - A. Avan - A. Baytok 11/1 (2019) 293-309 }
$$

There is relatively strong correlation between SL and PE ( $\mathrm{r}$. .553). This correlation can also be counted for the relationship between SL and OI (r: .488). Additionally, the relationship between PE and OI ( $\mathrm{r}$ : 525) is significant since the correlation coefficient higher than .50. These findings supported by the studies about subject topic. Van der Hoven (2014) ascertained that followers' perception of being empowered is positively relationship with supervisors' servant leadership behaviours. Similarly, Van Winkle et al. (2014) confirmed that followers' perceptions of being empowered were correlated with their perceptions of servant leadership behaviours. Similarly, the relationship between SL and OI is also supported by other studies in the literature. Zhang (2012) found that servant leadership was positively related to organizational identification. Chughtai (2016) stated that servant leadership is positively associated with organizational identification.

Regression analyses were performed in order to determine the potential effects and, also to test hypothesis of the study. In detail, SL is significantly affect PE and each increment at SL behaviours of supervisors increases PE level of participants at the rate of \%51. This finding also supported by Koyuncu et al. (2014) whom assigned that service employees have perceived higher level of servant leadership from their supervisors and Namasiwayam et al. (2014) claimed that leader empowering behaviours with regards to servant leadership influence on employees' PE, attitudes and organizational outcomes. Similarly, Baykal et al. (2018) suggest that SL has a positive effect on the perceptions of empowerment and gratitude felt by followers. Thus, SL behaviours are very important for enabling psychologically empowerment at hotel enterprises.

The results also contribute to literature by demonstrating that SL is a significant predictor of OI. Results demonstrate that SL behaviours of supervisors significantly affect OI and these behaviours represent \% 23 of organizational identification's total variance. The convergence of this finding with other studies' findings verified that SL behaviours are significant predictor of OI. Farrell and Oczkowski (2012), claim that employees who have more positive experiences with executives will have better identification level and will be much more customer oriented. Thomas et al. (2017) ascertained that servant leadership is positively associated with procedural justice, organizational collectivism, and organizational identification in family firms. Relevant convergency of the findings occurred in the field of hospitality studies (e.g. Chughtai, 2016; Schuh et al., 2012; Zhang et al., 2012; Zhao et al., 2016). Zhao et al. (2016), concluded that SL reduce the fear of being cling to supervisor and thus OI can be provided. Zhang et al. (2012), emphasize that servant leaders instil and reinforce the importance of serving individuals who are in or outside the organization. Accordingly, to serve others give important hints how it is a distinctive feature of organization

This study offers several opportunities for future research. In this study, potential relationships and effects among certain (pre-determined) variables has assessed. Mediating or moderation effects of some variables (such as trust, fit to organization and extra role behaviours) on research variables have not also mentioned. However, mediating/moderation role of empowerment and identification on SL, OC and OCB could be subjected in future studies.

This study also has some practical implications for hospitality organizations. A servant leader can motivate and improve employees by visionary behaviours, empowerment, trust, agapao love and humility. Additionally, his/her altruistic behaviours are essential for at the moment of service delivery process, and his/her service desire to others plays a vital role for unexpected problems or conflictions. Servant leaders also play a moderator role for developing some desired attitudes and behaviours among employees such as commitment, citizenship behaviour, embeddedness, job/work satisfaction. 


\section{References}

Allen, S., Winston, B. E., Tatone, G. R. and Crowson, H. M. (2018). Exploring a model of servant leadership, empowerment, and commitment in non-profit organizations. Nonprofit Management and Leadership, 29 (1), 123-140.

Asag-Gau, L. and van Dierendonck, D. (2011). The impact of servant leadership on organisational commitment among the highly talented: The role of challenging work conditions and psychological empowerment. European Journal of International Management, 5(5), 463-483.

Ashforth, B. E., Harrison, S. H. and Corley, K. G. (2008). Identification in organizations: An examination of four fundamental questions. Journal of Management, 34 (3), 325-374.

Ashforth, B. E. and Mael, F. (1989). Social identity theory and the organization. The Academy of Management Review, 14(1), 20-39.

Ashgar, A. and Naseer, S. (2017). The impact of servant leadership on follower's behaviors: The mediating role of psychological empowerment \& positive effect. Bahria University Journal of Management $\mathcal{E}$ Technology, 1 (2), 1-13.

Bass, B. M. (1985). Leadership and performance beyond expectations. New York: The Free Press.

Bass, B. M. (2000). The future of leadership in learning organizations. The Journal of Leadership Studies, 7(3), $18-40$.

Baykal, E., Zehir, C., and Kole, M. (2018). Effects of servant leadership on gratitude, empowerment, innovativeness and performance: Turkey example. Journal of Economy Culture and Society, 57, 29-52. https://doi.org/10.26650/JECS390903

Blau, P. M. (1964). Exchange and Power in Social Life. NY: Wiley.

Boyum, G. (2006). The historical and philosophical influences on greenleaf's concept of servant leadership, setting the stage for scientific theory building. Servant Leadership Research Roundtable, August, 1-12.

Brownell, J. (2010). Leadership in the Service of Hospitality. Cornell Hospitality Quarterly, 51(3), 363-378.

Cerff, K. and Winston, E. B. (2006). The inclusion of hope in the servant leadership model, an extension of Patterson and Winston's Models. Servant Leadership Research Roundtable, August.

Çetinkaya, A. Ş. and Yıldız, E. (2018). Hizmetkâr liderlik algisinin personel güçlendirmeye etkisi: Perakende sektörü çalişanlari araştirma. KMÜ Sosyal ve Ekonomik Araştırmalar Dergisi, 20(35), 1-11.

Chan, Y. H., Taylor, R. R. and Markham, S. (2008). The role of subordinates' trust in a social exchange-driven psychological empowerment process. Journal of Managerial Issues, 20 (4), 467.

Cheney, G. (1983). On the various and changing meanings of organizational membership: A field study of organizational identification. Communication Monographs, 50 (4), 342-362, DOI: $10.1080 / 03637758309390174$

Chughtai, A. A. (2016). Servant leadership and follower outcomes: Mediating effects of organizational identification and psychological safety, The Journal of Psychology, 150 (7), 866-880, DOI: $10.1080 / 00223980.2016 .1170657$

Conger, J. A. and Kanungo, R. N. (1988). The empowerment process: Integrating theory and practice. The Academy of Management Review, 13 (3), 471-482.

Conger, J. A. (1989). Leadership: The art of empowering others. The Academy of Management Executive, 3 (1), $17-24$.

Corsun, D. L. and Enz C. A. (1999). Predicting psychological empowerment among service workers: The effect of support-based relationships. Human Relations, 52 (2), 205-224. 
Ö. Zorlu - A. Avan - A. Baytok 11/1 (2019) 293-309

Dennis, R. S. and Bocarnea, M. (2005). Development of the servant leadership assessment instrument. Leadership \& Organization Development Journal, 26 (8), 600-615, https://doi.org/10.1108/01437730510633692.

Dutta, S. and Khatri, P. (2017). Servant leadership and positive organizational behaviour: The road ahead to reduce employees' turnover intentions. On the Horizon, 25 (1), 60-82, https://doi.org/10.1108/OTH-062016-0029.

Dutton, J. E., Dukerich, J. M. and Harquail, C. V. (1994). Organizational images and member identification. Administrative Science Quarterly, 39 (2), 239-263.

Farling, M. L., Stone, A. G. and Winston, B. E., (1999). Servant leadership: Setting the stage for empirical research. The Journal of Leadership Studies, 6 (1-2), 49-72.

Farrell, M. A. and Oczkowski, E. (2012). Organisational identification and leader member exchange influences on customer orientation and organisational citizenship behaviours. Journal of Strategic Marketing, 20 (4), 365-377, DOI: 10.1080/0965254X.2011.643917.

Frenkel, S. J. and Yu, C. (2011). Managing coworker assistance through organizational identification. Human Performance, 24 (5), 387-404, DOI: 10.1080/08959285.2011.614301.

Gautam, T., Dick, R. V. and Wagner, U. (2004). Organizational identification and organizational commitment: Distinct aspects of two related concepts. Asian Journal of Social Psychology, 7 (3), 301-315, https://doi.org/10.1111/j.1467-839X.2004.00150.x

Gkorezis, P., Hatzithomas, L. and Petridou, E. (2011). The impact of leader's humor on employees' psychological empowerment: The moderating role of tenure. Journal of Managerial Issues, 23 (1), 83-95.

Graham, J. W. (1991). Servant leadership in organizations: Inspirational and moral. The Leadership Quarterly, 2 (2), 105-119.

Graham, J. W. (1995). Leadership, moral development, and citizenship behavior. Business Ethics Quarterly, 5 (1), 43-54.

Greasley, P. E. and Bocarnea, M. (2014). The relationship between personality type and the servant leadership characteristic of empowerment. Procedia - Social and Behavioral Sciences, 124, 11-19.

Jaiswal, N. K. and Dhar, R. L. (2017). The influence of servant leadership, trust in leader and thriving on employee creativity. Leadership $\mathcal{E}$ Organization Development Journal, 38 (1), 2-21, https://doi.org/10.1108/LODJ-02-2015-0017

Khajehpour, N., Baharlou, M., Beshlideh, K. and Yeganeh, M. M. (2016a). The effect of servant leadership on organizational commitment: The mediating role of psychological empowerment and organizational justice. International Journal of Psychology, 10 (2), 55-81.

Khajehpour, N., Baharlou, M., Yeganeh, M. M. and Hashemei, S-E., (2016b). The mediating role of psychological empowerment and organizational justice in the relationship of servant leadership with job satisfaction, organizational citizenship behavior and organizational commitment. International Journal of Behavioral Science, 10 (3), 99-105.

Kim, B (P)., Lee, G., Murrmann, S. K., and George, T. R. (2012). Motivational effects of empowerment on employees' organizational commitment: A mediating role of management trustworthiness. Cornell Hospitality Quarterly, 53 (1), 10-19.

Van Knippenberg, D., and Van Schie, E. C. (2000). Foci and correlates of organizational identification. Journal of occupational and organizational psychology, 73(2), 137-147.

Koyuncu, M., Burke, R.J., Astakhova, M., Eren, D. and Cetin, H. (2014). Servant leadership and perceptions of service quality provided by front-line service workers in hotels in Turkey: Achieving competitive advantage. International Journal of Contemporary Hospitality Management, 26(7), 1083-1099, https://doi.org/10.1108/IJCHM-06-2013-0238 
Ö. Zorlu - A. Avan - A. Baytok 11/1 (2019) 293-309

Liden, R. C., Wayne, S. J., Zhao, H. and Henderson, D. (2008). Servant leadership: Development of a multidimensional measure and multi-level assessment. The Leadership Quarterly, 19, 161-177.

Mael, F. and Ashforth, B. E. (1992). Alumni and their alma mater: A partial test of the reformulated model of organizational identification. Journal of Organizational Behavior, 13, 103-123.

Menon, S. (2001). Employee empowerment: An integrative psychological approach. Applied Psychology, 50(1), 153-180.

Namasiwayam, K., Guchait, P. and Lei, P. (2014). The influence of leader empowering behaviors and employee psychological empowerment on customer satisfaction. International Journal of Contemporary Hospitality Management, 26(1), 69-84, https://doi.org/10.1108/IJCHM-11-2012-0218

Newman, A., Schwarz, G., Cooper, B. and Sendjaya, S. (2017). How servant leadership influences organizational citizenship behavior: The roles of LMX, empowerment, and proactive personality. Journal of Business Ethics, 145, 49-62.

Organ, D. W. (1988). Organizational Citizenship Behavior and the Good Soldier. In M. G. Rumsey, C. B. Walker and J. H. Harris (Eds.), Personnel Selection and Classification, Chapter 4, Lexington, MA, England: Lexington Books.

Page, D. and Wong, P.T.P. (2000). A Conceptual Framework for Measuring Servant-Leadership, In S.Adjibolosoo (Ed.), The human factor in shaping the course of history and development, Boston, MA: University Press of America.

Patchen, M. (1970). Participation, achievement and involvement in the job. Englewood Clifs, NJ: Prentice Hall.

Patterson, K. (2003). Servant leadership: A theoretical model (Unpublished doctoral dissertation), Regent University, VA Beach, VA.

Qi, Y. and Ming-Xia, L. (2014) Ethical leadership, organizational identification and employee voice: Examining moderated mediation process in the Chinese insurance industry. Asia Pacific Business Review, 20 (2), 231-248, DOI: 10.1080/13602381.2013.823712.

Quinn, R. E. and Spreitzer, G. M. (1997). The road to empowerment: Seven questions every leader should consider. Organizational Dynamics, 26 (2), 37-49.

Riketta, M. (2005). Organizational identification: A meta-analysis. Journal of Vocational Behavior, 66(2), 358384.

Riketta, M. and Dick, R. F. (2005). Foci of attachment in organizations: A meta-analytic comparison of the strength and correlates of workgroup versus organizational identification and commitment. Journal of Vocational Behavior, 67 (3), 490-510, doi:10.1016/j.jvb.2004.06.001.

Russell, R. F. (2001). The role of values in servant leadership. Leadership \& Organization Development Journal, 22 (2), 76-84, https://doi.org/10.1108/01437730110382631.

Russell, R. F. and Stone, A. G. (2002). A review of servant leadership attributes: developing a practical model. Leadership $\mathcal{E}$ Organization Development Journal, 23 (3), 145-157, https://doi.org/10.1108/01437730210424.

Schuh, S. C., Egold, N. W. and Dick, R. V. (2012) Towards understanding the role of organizational identification in service settings: A multilevel study spanning leaders, service employees, and customers. European Journal of Work and Organizational Psychology, 21 (4), 547-574, DOI: $10.1080 / 1359432 X .2011 .578391$.

Sendjaya, S. and Pekerti, A. (2010). Servant leadership as antecedent of trust in organizations. Leadership $\mathcal{E}$ Organization Development Journal, 31 (7), 643-663, https://doi.org/10.1108/01437731011079673.

Sendjaya, S. and Sarros, J. C. (2002). Servant leadership: Its origin, development, and application in organizations. Journal of Leadership and Organization Studies, 9 (2), 57-64. 
Ö. Zorlu - A. Avan - A. Baytok 11/1 (2019) 293-309

Sendjaya, S., Sarros, J. C. and Santora, J. C. (2008). Defining and measuring servant leadership behaviour in organizations, Journal of Management Studies, 45 (2), 402-424.

Sousa, M. and van Dierendonck, D. (2017). Servant leaders as underestimators: Theoretical and practical implications. Leadership $\mathcal{E}$ Organization Development Journal, 38 (2), 270-283, https://doi.org/10.1108/LODJ-10-2015-0236.

Spears, C. L. (2010). Character and servant leadership: Ten characteristics of effective, caring leaders. The Journal of Virtues \& Leadership, 1 (1), 25-30.

Spears, L. C. (2004). Practicing servant-leadership. Leader to Leader, 34, 7-11.

Spreitzer, G. M. (1995), Psychological empowerment in the workplace: Dimensions, measurement, and validation. Academy of Management Journal, 38 (5), 1442-1465.

Spreitzer, G. M., Kizilos M. A, and Nason, S. W., (1997). A dimensional analysis of the relationship between psychological empowerment and effectiveness, satisfaction, and strain. Journal of Management, 23 (5), 679-704.

Stone, A. G., Russell, R. F. and Patterson, K. (2004). Transformational versus servant leadership: a difference in leader focus. Leadership \& Organization Development Journal, 25 (4), 349-361, https://doi.org/10.1108/01437730410538671.

Tajfel, H. and Turner, J. C. (1986). The Social Identity Theory of Intergroup Behavior. In S. Worchel and W. G. Austin (Eds.), Psychology of Intergroup Relations (pp. 7-24). Nelson, Hall Publishers.

Thomas, C. H., Craig, J. B., Dibrell, C. and Marshall, D. R. (2017). Servant leadership and organizational identification: A family firm perspective. In Academy of Management Proceedings, Vol. 2015, No. 1, Christopher H. Thomas, Justin B Craig, Clay Dibrell and David Ross Marshall.

Thomas, K. W. and Velthouse, B. A. (1990). Cognitive elements of empowerment: An "interpretive" model of intrinsic task motivation. The Academy of Management Review, 15 (4), 666-681.

Turner, J. C. (1984). Social identification and psychological group formation. In H. Tajfel (Ed.), The Social Dimension: European Studies in Social Psychology, Volume 2, (pp. 518-538). Cambridge, Cambridge University Press.

van der Hoven, A.G. (2014). The influence of servant leadership on trust, psychological empowerment, job satisfaction and organisational citizenship behaviour on a selected sample of teachers in the Western Cape Province, Master Thesis, Department of Industrial Psychology, University of the Western, Canada.

van Dierendonck, D. (2011). Servant leadership: A review and synthesis. Journal of Management, 37 (4), 12281261, DOI: $10.1177 / 0149206310380462$.

van Dierendonck, D. and Nuijten, I. (2011). The servant leadership survey: development and validation of a multidimensional measure. Journal of Business and Psychology, 26 (3), 249-267.

van Dierendonck, D., Stam, D., Boersma, P., de Windt, N. and Alkema, J. (2014). Same difference? Exploring the differential mechanisms linking servant leadership and transformational leadership to follower outcomes. The Leadership Quarterly, 25 (3), 544-562.

van Winkle, B., Allen, S., DeVore, D. and Winston, B. (2014). The relationship between the servant leadership behaviors of immediate supervisors and followers' perceptions of being empowered in the context of small business. Journal of Leadership Education, 13(3), 70-82, https://do1.org/1012806/V13/I3/R5

Vondey, M. (2010). The relationships among servant leadership, organizational citizenship behavior, personorganization fit, and organizational identification. International Journal of Leadership Studies, 6 (1), 3-27.

Waddell, T. J. (2006). Servant leadership. Servant Leadership Research Roundtable, August.

Walumbwa, F.O., Hartnell, C.A. and Oke, A. (2010). Servant leadership, procedural justice climate, service climate, employee attitudes, and organizational citizenship behavior: A cross-level investigation. Journal of Applied Psychology, 95 (3), 517-529. 
Ö. Zorlu - A. Avan - A. Baytok 11/1 (2019) 293-309

Winston, B. (2003). Extending Patterson's servant leadership model: Explaining how leaders and followers interact in a circular model. Servant Leadership Research Roundtable, August.

Zhang, H., Kwan, H. K., Everett, A. M., and Jian, Z. (2012). Servant leadership, organizational identification, and work-to-family enrichment: The moderating role of work climate for sharing family concerns. Human Resource Management, 51 (5), 747-768.

Zhang, Y., Lin, T-B. and Foo, S. F. (2012). Servant leadership: A preferred style of school leadership in Singapore, Chinese Management Studies, 6 (2), 369-383, https://doi.org/10.1108/17506141211236794.

Zhao, C., Liu, Y. and Gao, Z. (2016). An identification perspective of servant leadership's effects. Journal of Managerial Psychology, 31(5), 898-913, https://doi.org/10.1108/JMP-08-2014-0250.

Zhao, H., Peng, Z. and Chen, H-K. (2014). Compulsory citizenship behavior and organizational citizenship behavior: The role of organizational identification and perceived interactional justice. The Journal of Psychology, 148 (2), 177-196, DOI: 10.1080/00223980.2013.768591 